\title{
Study on Small and Medium-Sized Enterprises in Italy: The Relationship With the Banking System and Financial Structure Choices
}

\author{
Pietro Pavone \\ Ministry of Economy and Finance, Milano, Italy \\ Francesco Zappia \\ eCampus University, Novedrate, Italy
}

This work presents the main theoretical guidelines in order to understand the relationship between banks and enterprises in the Italian economical context. It begins by looking into the matter of coverage of the companies' financial needs and it proposes an analysis of the financial structure of small and medium-sized enterprises in Italy, in the years between 2007 and 2012. The subject of studying capitalization of small and medium-sized Italian enterprises and of access to external sources of funding represents an effective synthesis between the qualitative approach of the most important mentioned theories and the quantitative analysis of recent Italian situation. This paper, while depicting the main challenges in the relationship between banks and small and medium-sized enterprises, focuses on the weaknesses of the latter's financial structure, offering useful means to reach a desirable financial new equilibrium. There are many different implications, both from a practical and a social point of view: the wavering economic trend, the frequent enterprise crises and the continuous make the start of processes of patrimonial strengthening and the research for a more stable financial equilibrium, by the diversification of sources of funding. Furthermore, looking into this matter makes it possible to reach a strategic, long-term point of view on the sustainability of the Italian economic-productive system.

Keywords: small and medium-sized enterprise, bank, financial structure, financial needs

\section{Introduction}

The Italian industrial system is characterized by a low degree of economic concentration and by the great presence of enterprises of small dimensions.

The interest in this kind of enterprises is substantially tied to their often-positive performances, even at times of economic downturn, achieved by these institutions.

Pietro Pavone, Ministry of Economy and Finance, Milano, Italy.

Francesco Zappia, expert in the field of Public Finance, eCampus University, Novedrate, Italy.

Correspondence concerning this article should be addressed to Pietro Pavone, via Paolucci Di Calboli Fulcieri n. 10, Milano 20162, Italy. 
The aim of this work is to examine the relationship between the Bank and SMEs ${ }^{1}$ in Italy, in light of the main theoretical and empirical contributions of the last years, analyzing available data on the phenomenon.

Specifically, the paper means to answer the following questions:

- is it possible to trace the characteristics of the financial needs of Italian SMEs?

- which are the most important means of coverage of those needs typical of SMEs in Italy?

- which is the function of banking debt?

- seen the recent trends on the relationship bank-enterprise, how is it possible to intervene for a more effective governing of enterprise financial needs?

In its first part, the paper deals with a revisiting of Italian publications with some conceptual remarks, regarding the most important scientific theories which represent the base to interpret the origins of smaller enterprises in Italy and the historical relationship between those and the local banks.

Then, by illustrating recent data taken from balance sheets of Italian small and medium-sized enterprises, some typical characteristics of Italian PMIs are highlighted, referring particularly to the composition of their capital liability.

The attention is focused on questions of financial nature: first, there is an analysis of effects regarding the choice between debt capital and venture capital in the coverage of the enterprises' financial needs ${ }^{2}$, to then proceed to delineate the main reasons for tension in the financial structure of balance sheets of small and medium-sized Italian enterprises ${ }^{3}$.

Concluding, the work gets some considerations: the issues concerning the government of the financial needs, common to all enterprises, are more marked and clearer in balance sheets of smaller enterprises. To improve the historically conflictual relationship between enterprises and banks in Italy, first of all, it is needed to look for a new balance in the financial structure of enterprises by a more thought-out financial programming.

\section{Research Approach and Literature Review}

Many theories deepen the knowledge of the role of SMEs inside an industrial system.

The most notorious theory is Penrose's (1959): small and medium-sized business realities would be generated from the empty spaces which big enterprises do not cover, overlooking business opportunities that are less attractive and less fit for their characteristics.

Regarding relationship with the banking system, according to Conti (1999), in Italy there are two kinds of bank-enterprise relations: the first is the one that, during the industrial revolution, made it possible for Italy to acquire active enterprises in high-capital-intensity sectors (top-down approach for financing, by a careful Statal directing). The second model (De Bruyn \& Della Valle, 1997) was born from the financial needs of SMEs, the one discussing local and people's banks (a model taking shape from the low: from the territory).

The first theory refers to the Shumpeterian approach, which considers the banking system as a creator of purchasing power destined to innovation funding, the second sees the bank acting like simply a provider of

\footnotetext{
${ }^{1}$ This paper for Small and Medium-Sized Enterprises (SMEs) refers to definition given by the European Union (Commission Recommendation 2003/361/EC). The main factors determining whether an enterprise is an SME are: staff headcount either turnover or balance sheet total. Medium-sized enterprise has less than 250 employees and turnover of or less than 50 million or balance sheet total of or less than 43 million. Small enterprise has less than 50 employees and turnover of or less than 10 million or balance sheet total of or less than 10 million.

${ }^{2}$ It's possible to reconnect the financial needs to two requirements: coverage for fixed investments and financement of working capital.

${ }^{3}$ A consequence of the frailty of financial structures an improper transfer of risk of enterprises (Bisoni \& Ferrari, 2012).
} 
funds for enterprises with the lowest risk appetite, often overlooking the evaluation of their innovation ability or their growth potential.

Another relevant problem, relevant both from the scientific and the pragmatic point of view, is that of the applicability of corporate finance to small and medium-sized enterprises. A number of studies and research papers have been published on the matter, fueling a debate which articulated in different moments and in an equal number of research efforts: according to a first theoretical strand, theories of corporate finance are not useful to evaluate the state of health of SMEs: the analysis of singular matters of small enterprises induces to refuse corporate finance paradigms because SMEs bring out new financial management issues, asking for different solutions ${ }^{4}$.

According to a different approach, whatever the genesis of financing needs, it is necessary to maximize the positive impact of leverage by the typical corporate finance analysis.

Moving on from these theoretical considerations, the study offers an examination of strengths and weaknesses of different choices of financing needs coverage, distinguishing between internal and external sources of funding and by looking at a significant sample of small and medium-sized enterprises (considered to be such according to the specific parameters of the 2003 European Commission definition) it comes to delineating the typical characteristics of the composition of liability of Italian SMEs, offering insights to interpret new tendencies in the relationship between banks and small and medium-sized enterprises in Italy.

In the mature phase, when the enterprise enjoys a satisfying reputation on financial markets, sources of funding can be directed towards more complex financial instruments (for instance, bond debt and shares issue), the latter a rocky path for SMEs, but more easily viable for large companies.

\section{The Role of SMEs in the Italian Economic Environment and Their Relationship With Banks}

Italy is the country which can claim the highest number of SMEs in the European Union. In the Italian economic environment, small and medium-sized enterprises contribute largely to the formation of GDP and are active players in economic development.

They benefit from some typical features: resilience, organization flexibility and the subsequent decision-making promptness which make it possible for these enterprises to respond at a higher speed and more effectively to demand shifts.

Small dimensions, for a long time, have represented an element of great dynamism for the Italian production system but today, in a globalized world, smaller sizes threaten to become a limit undermining competitiveness.

A traditional characteristic of SMEs lies in the relational paradigm, at the basis of relationships with local and rooted-in-the-area banks. Some authors (Conti, 1999; Conti \& Ferri, 1997) have indicated the long-period existence of a network of local banks supporting credit needs of smaller enterprises.

In this regard it has been talked about size effect, to indicate a credit specialization: big banks tend to offer credit especially to big companies, while small banks to SMEs. The root reason for this specialization would be that granting loans to SMEs is a different activity from allocating funding to big enterprises and calls for a loan

\footnotetext{
${ }^{4}$ If, from one side, the economic theories do not provide clearly different models for smaller enterprises, from another, the empirical investigations collide with the little transparency shown by these.
} 
technology which becomes burdening for big banks and beneficial for local minor ones ${ }^{5}$ (Costa \& Costagli, 2004).

De Cecco (2001) believes that the steady presence of small enterprise in Italy is, in part, due to the financial allocation of Italian family business, which often does not make clear difference between family finance and business finance. In other words, the organization of the financial system would be one of the main reasons for the dwarfism of Italian enterprises, as a result of a mechanism in which the affected players would gain advantage by keeping enterprises small: banks are because with multiple entrustment they minimize credit risk and entrepreneurs because they can avoid losing control of their enterprise.

\section{Financial Structure of Italian SMEs}

According to a shared opinion, issues concerning development financing of the enterprise change according to the status they hold on their life cycle.

Enterprise surely needs sources when it is new and small and therefore it does not have a sufficiently accomplished reputation to rely on in its relationship with investors (in this phase financing is carried out with the initial endowment capital and with cash flow generated by management).

Some authors (Calcagnini \& Demartini, 2009) referred to this matter with the term-financial gap, working on the disadvantage of small enterprises, meaning that the difficulties of entering the capital market are bigger when the enterprise is smaller and younger, even when characterized by a high development potential.

Challenges do not become more acute in the next phase, the one in which the enterprise tends to grow: the expansion of investment projects is normally accompanied to an increasing risk profile and a greater financing need (this is the phase in which it is needed to diversify different sources of funding combining bank loans with venture capital funding).

In the maturation phase, when companies have a good reputation in the financial markets, more complex forms of financing are possible (such as debt bonds and issue of shares): this is more difficult for SMEs and easier for big companies.

\begin{tabular}{|c|c|c|}
\hline $\begin{array}{c}\text { Financial structure of the START-UP } \\
\text { company }\end{array}$ & $\begin{array}{c}\text { Financial structure of the company under } \\
\text { GROWTH }\end{array}$ & $\begin{array}{c}\text { Financial structure of the MATURE } \\
\text { company }\end{array}$ \\
\hline internal funding > external funding & \multicolumn{2}{|c|}{ external funding > internal funding } \\
\hline
\end{tabular}

Figure 1. Evolution of the financial structure in the growth of SMEs.

The enterprises that have an asset value consisting of options of developing, as in possibilities of future investments of which the cost-effectiveness is not known (Buffetti, 1985), are not able to use classical-debt instruments, but they could proceed researching and eventually realize development operations by raising venture capital for growth.

\footnotetext{
${ }^{5}$ SMEs are more diverse: this makes standardization of assessment criteria of creditworthiness disadvantageous and therefore hampers use of economies of scale.
} 
The main channels for coverage of financing needs are:

- self-financing, produced inside the enterprise, without recurring to third-part economies' means;

- debt capital, constituted of the combination of constraints burdening the enterprise as a consequence of debts owed to third-part financiers;

- venture capital, the part of capital which supports entirely business risk.

The key feature of bank financing is inflexibility: banks struggle to give space to enterprises that have valid projects but a low degree of capital strength.

In those circumstances, a solution lies in the use of the risk capital, which represents a flexible source of financing (Rija, 2006).

Table 1

Comparison Between Financing With Venture Capital and Financing With Debt Capital

\begin{tabular}{lll}
\hline & Venture capital & Debt capital \\
\hline Timeframe & Medium to long term & Short, medium to long term \\
\hline Maturities & No prediction of maturities & Predicts maturities \\
\hline Type & Flexible source useful to finance growth processes & Inflexible source with limited access possibility \\
\hline Remuneration & Depends on the growth of enterprise value & Regular payment of interest \\
\hline Services & $\begin{array}{l}\text { Who invests in venture capital can provide strategical } \\
\text { and financial advice }\end{array}$ & $\begin{array}{l}\text { Provided assistance is exclusively subsidiary to } \\
\text { financing }\end{array}$ \\
\hline
\end{tabular}

Source: AIFI, practical guide to venture capital.

As it becomes clear in the following, in Italy, enterprises use almost exclusively banking credit institutes to obtain financing, with a consequential imbalance of financial structure.

The following tables show the composition of balance-sheet liability of small and medium-sized enterprises in the time between 2007 and 2012 with emphasis on the variation of main components of the liability ${ }^{6}$.

Table 2

Composition of the Liability From 2007 to 2012 (Absolute Values) ${ }^{7}$

\begin{tabular}{|c|c|c|c|c|c|c|}
\hline Liabilities & 2007 & 2008 & 2009 & 2010 & 2011 & 2012 \\
\hline Total payables & 329.4 & 349.8 & 348.8 & 377.1 & 400.8 & 394.1 \\
\hline Due to banks & 111.6 & 122.7 & 124.6 & 134.7 & 144.1 & 140.3 \\
\hline Due to other lenders & 9.3 & 9.3 & 8.5 & 8.2 & 9.1 & 9.3 \\
\hline Due to providers & 106 & 104 & 99.5 & 109.4 & 118 & 112.8 \\
\hline Other payables & 102.5 & 113.9 & 116.2 & 124.8 & 129.5 & 131.7 \\
\hline Short-term payables & 259 & 267.7 & 258.7 & 278.2 & 297.8 & 293.8 \\
\hline Long-term payables & 70.4 & 82.1 & 90.1 & 99 & 103 & 100.3 \\
\hline Equity & 172.7 & 206.6 & 214.1 & 221.8 & 226.7 & 233 \\
\hline Total liabilities and equity ${ }^{8}$ & 535.3 & 592.9 & 600.7 & 638.2 & 668.1 & 668.6 \\
\hline
\end{tabular}

It can be inferred from the presented data that bank debt is broadly predominant between financing sources of smaller Italian enterprises. Also, there is a high short-term exposure in debts owed to banks.

\footnotetext{
${ }^{6}$ The considered sample is composed of 46,868 Italian SMEs with a turnover ranging from five to 10 million euros as to 31.12.2012 (data mining by AIDA database by Small \& Medium Enterprises Knowledge Center-SDA Bocconi).

${ }^{7}$ Values in billions of euros.

${ }^{8}$ Also considering reserves, severance pay, accruals, prepayments, and deferred income.
} 
2008's financial crisis has interrupted the process of greater capital strength of Italian enterprises. Along with the crisis enterprises’ budgets have become weaker: capital has diminished and loans have grown back up.

Table 3

Composition of the Liability From 2007 to 2012 (Percentages)

\begin{tabular}{lllllll}
\hline Liabilities & 2007 & 2008 & 2009 & 2010 & 2011 & 2012 \\
\hline Total payables & $61.5 \%$ & $59 \%$ & $58.1 \%$ & $59.1 \%$ & $60 \%$ & $58.9 \%$ \\
Due to banks & $20.8 \%$ & $20.7 \%$ & $20.7 \%$ & $21.1 \%$ & $21.6 \%$ & $21 \%$ \\
Due to other lenders & $1.7 \%$ & $1.6 \%$ & $1.4 \%$ & $1.3 \%$ & $1.4 \%$ & $1.4 \%$ \\
Due to providers & $19.8 \%$ & $17.5 \%$ & $16.6 \%$ & $17.1 \%$ & $17.7 \%$ & $16.9 \%$ \\
Other payables & $19.1 \%$ & $19.2 \%$ & $19.3 \%$ & $19.6 \%$ & $19.4 \%$ & $19.7 \%$ \\
Short-term payables & $48.4 \%$ & $45.2 \%$ & $43.1 \%$ & $43.6 \%$ & $44.6 \%$ & $43.9 \%$ \\
Long-term payables & $13.2 \%$ & $13.8 \%$ & $15 \%$ & $15.5 \%$ & $15.4 \%$ & $15 \%$ \\
Equity & $32.3 \%$ & $34.8 \%$ & $35.6 \%$ & $34.8 \%$ & $33.9 \%$ & $34.8 \%$ \\
Total liabilities and equity & $100 \%$ & $100 \%$ & $100 \%$ & $100 \%$ & $100 \%$ & $100 \%$ \\
\hline
\end{tabular}

Source: AIDA database.

Accordingly, the debit/own funds ratio is very high, of which the trend is shown as registered in the time between 2007 and 2012:

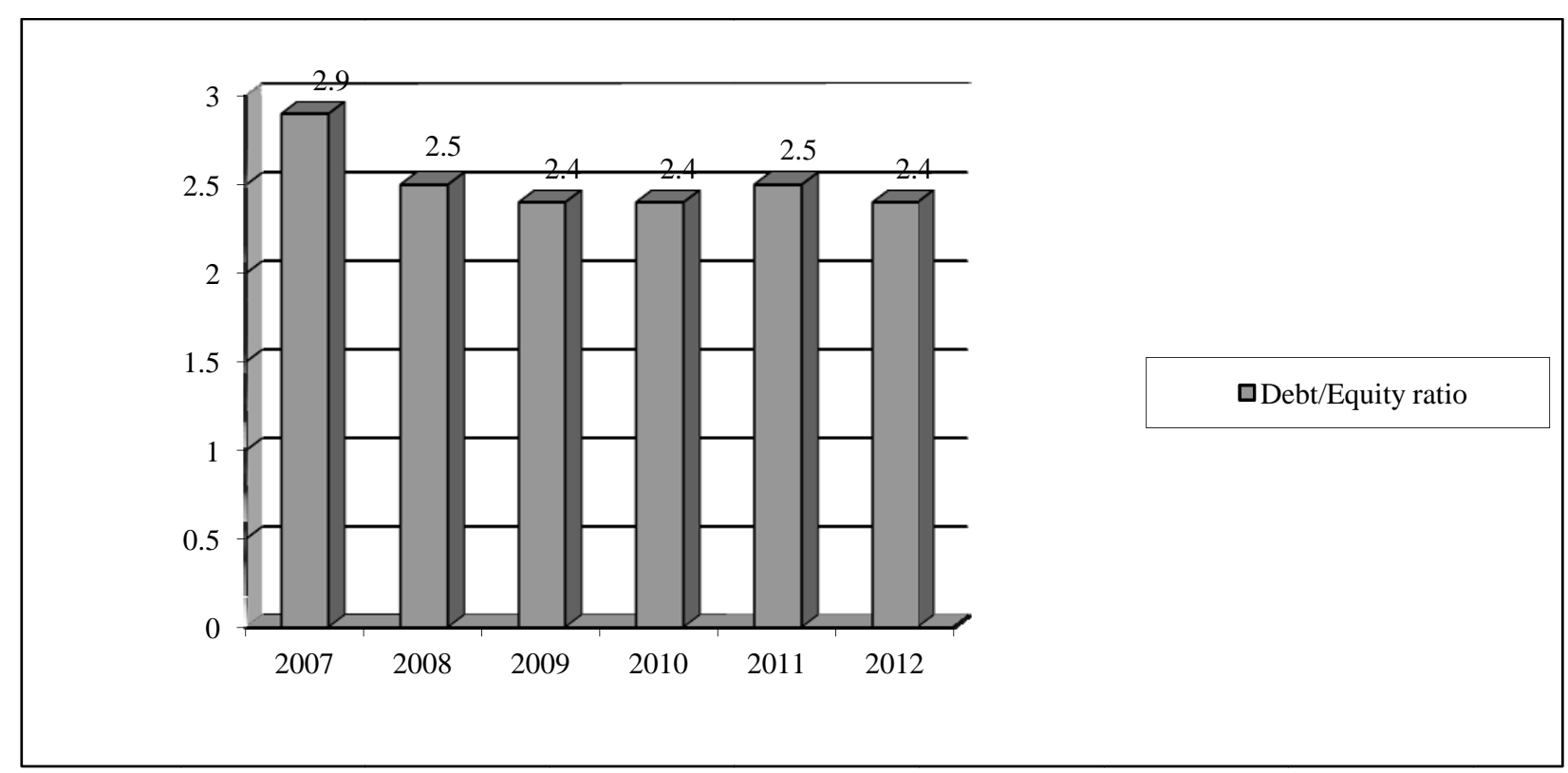

Figure 2. Debt/equity ratio trend from 2007 to 2012.

Despite the fact that Debit/Net Asset decreased by 0.5 points from 2007 to 2012, going from 2.9 to 2.4, SMEs still show a very high leverage.

The following figure shows the trend, in the same time span, of financial debts and commercial debts in Italian SMEs' budget ${ }^{10}$ (index: $2007=100$ ).

\footnotetext{
${ }^{9}$ Also considering reserves, severance pay, accruals, prepayments, and deferred income.

${ }^{10}$ Cerved data.
} 


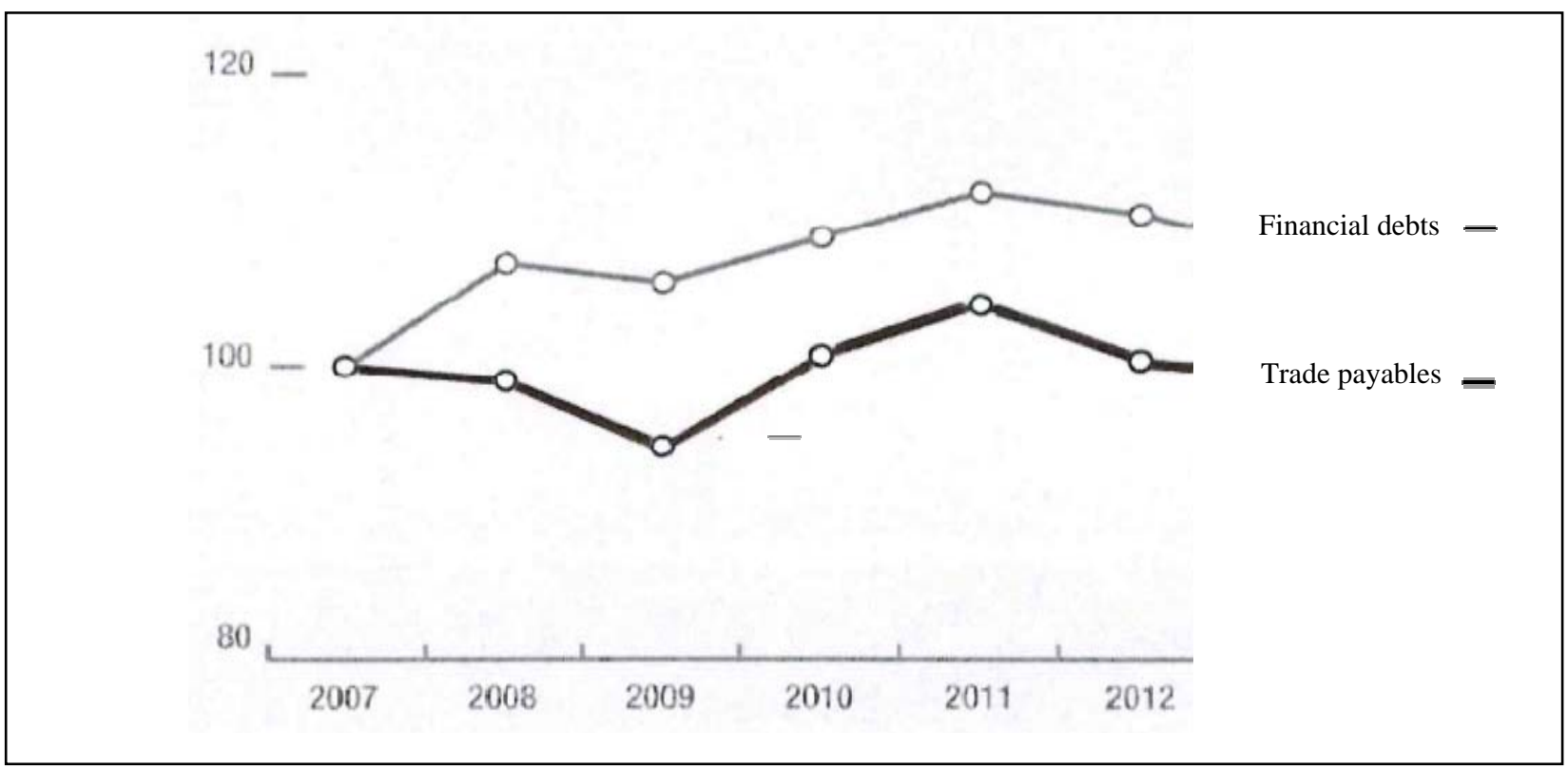

Figure 3. Financial debts and trade payables of the SMEs.

Therefore, the long crisis that hit Italian SMEs' system from 2008 coincided with a much more severe selection on credit, not only from banks, but also from the very same enterprises when granting commercial credit to their clients.

The trend of the line concerning financial debts is confronted below with the one recorded in big enterprises' budget ${ }^{11}$ (index: $2007=100$ ):

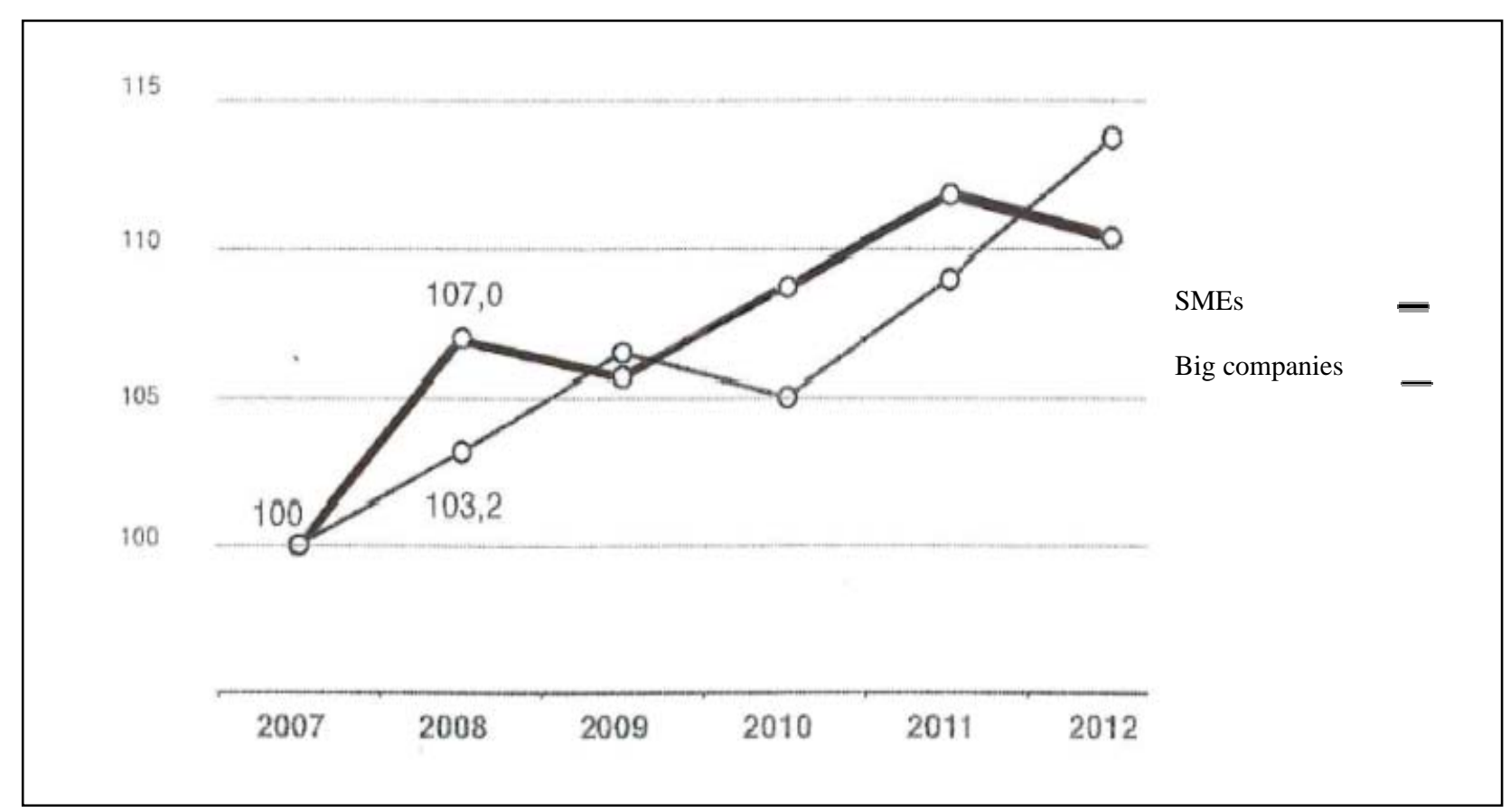

Figure 4. Financial debts: SMEs and big companies.

\footnotetext{
${ }^{11}$ Cerved data.
} 
It follows that until 2008 bank loans have grown at a rapid pace and then slowed down rapidly; from 2011, the amount of loans has shrunk again.

The trend of financial debts shown in Figure 4 stresses that the phenomenon concerned first, and to a greater extent, SMEs than big enterprises: between 2011 and 2012 SMEs have reduced financial debts while they grew to big companies in 2012.

Between the most self-evident peculiarities in the relationship bank-enterprise, the empirical analysis always highlighted the one of multibanking, particularly widespread in Italy. In international comparisons, Italy stands out for the highest number of trusting banks per enterprise ${ }^{12}$. A Ongena and Smith's (2000) study on European enterprises has detected the use of, on average, 2.3 contemporary credit relationships in Norway, 2.5 in Sweden, 2.9 in the United Kingdom, 8 in Germany, between 10 and 11 in Portugal, France, Belgium, and Spain, reaching 15.2 in Italy.

This is a phenomenon which permits to maintain multiple relationships with different credit institutions simultaneously and which fulfils both the needs of borrowers and the needs of those who grant funding: enterprises can reach more beneficial contractual preconditions preventing banks from benefitting from an exclusive relation, while banks distribute risks with other credit institutions.

Many authors allege a positive correlation between business size and number of bank-enterprise relationships. However, it is believed that this is not enough to explain the intensity of the phenomenon of multibanking. A Brasili and Vulpes's (2005) analysis shows that there is still a significant percentage of small and medium-sized enterprises with more than six banks (respectively 22\% of enterprises with a turnover lower than five million euros and 55\% of those with a turnover from five million to 10 million euros).

\section{Found Criticalities and Hypothesis of Future Development}

The indebtedness with banks should be characterized by means consistent with the general outline of financial needs. Instead, according to the presented data, SMEs' financial profile was defined as overall weak and excessively reliant on the banking system, displaying that bank debt is skewed towards the short term $^{13}$.

The aforementioned excessive reliance on banks highly exposes companies to external changes: in the first place, a change in the banking system's propensity to provide financing (also influenced by exogenous factors like the policies of the European Central Bank as well as the stricter and stricter requirements imposed by the rules of Basel $\mathrm{III}^{14}$ ).

In light of the considerations above, the financial component requires a proper planning intended to assess not only the financing transaction's technical factors, but also the adequate means of financial security. It follows that entrepreneurs have to carry out a proper cost-benefit analysis before making contact with the representatives prepared to grant financing. Furthermore, the excessive fragmentation of commitments stimulates the growth of short-term debt and is likely to worsen enterprises' financial fragility through an imbalanced financial structure and a high incidence of borrowing costs on the economic outturn account.

\footnotetext{
12 This peculiarity in Italy has historical origins in prudential supervision rules, aiming to limit exposure of credit institutions relating to single borrowers (Forestieri \& Tirri, 2003).

${ }_{13}$ Italian SMEs often have inadequate liquid assets compared to short-term operative needs.

${ }^{14}$ Innovation of rules regarding capital and liquid assets standards required by Basel III, even if providing stability to the scheme, in the short term can halt loan granting (source: Bank of Italy).
} 


\section{Conclusions}

The concluding considerations have the aim to help extend interpretative schemas on a crucial theme for the Italian economic system: the choice of SMEs' financial structure and their relationship with the banking system.

It has been emphasized that the difficulties encountered by SMEs in accessing bank financing are one of the factors limiting their growth.

An analysis has been exposed, inferred from the study of a wide sample of small and medium enterprises, in which tangible results have been shown over the baseline theoretical framework.

The study of SME finance has been carried out taking into due consideration the peculiarity of smaller enterprises' financial structure and their relationship with the banks compared with the world of big business. Research carried out along this line has identified the existence of a financial gap, namely the difficulties encountered by enterprises with growth potential in acquiring mid to long-term maturity venture and debt capital, necessary to carry out development projects.

The prevailing use of self-financing and bank credit soon shows evidence of this gap. In particular, small enterprises would suffer a credit crunch which disadvantages them compared to big enterprises, especially in times of restrictive monetary policies.

The solution to support enterprises' investment surely cannot be the one of bank debt.

There must be firm focusing on the lever of equity, that is on entrepreneurs' and external investors' capital (external equity).

Ultimately, there is no absolutely excellent financial structure at which Italian SMEs should aim, but from the consideration of strict balance-sheet index, it would be appropriate to move on to the more flexible and broader concept of debt sustainability.

Sustainability can be measured as a possibility of coverage of financial burden in the income statement by generating an adequate operating income; furthermore, as capital repayment ability; then, as the capacity of the enterprise to generate resources to fuel development, net of financial transactions (Calcagnini \& Demartini, 2009).

\section{References}

Bisoni, C., \& Ferrari, A. (2012). Il rapporto banca-impresa: superare antichi problemi e affrontare nuove sfide. Bancaria.

Brasili, A., \& Vulpes, G. (2005). Co-movement in EU banks’ fragility: A dynamic factor model approach. Mimeo.

Buffetti, P. (1985). Dal capitale di credito al capitale di rischio. Tesi e proposte per il rafforzamento della struttura finanziaria delle imprese. Milano: FrancoAngeli.

Calcagnini, G., \& Demartini, P. (Eds.). (2009). Banche e PMI: “Le regole dell'attrazione”. Strumenti di riflessione su vincoli e opportunità di Basilea 2 per lo sviluppo delle piccole e medie imprese. Milano: FrancoAngeli.

Conti, G. (1999). Le banche e il finanziamento industriale. In F. Amatori, D. Bigazzi, R. Giannetti, and L. Segreto (Eds.), Storia d'Italia. Annali 15 (pp. 441-504). Torino: Einaudi.

Conti, G., \& Ferri, G. (1997). Banche locali e sviluppo economico decentrato. In F. Barca (Ed.), Storia del capitalismo italiano dal dopoguerra ad oggi (pp. 429-465). Roma: Donzelli.

Costa, S., \& Costagli, S. (Eds.). (2004). Proceedings from XVI conferenza della Società Italiana di Economia Pubblica: I rapporti tra Banca-PMI in Italia: considerazioni a margine del dibattito. Pavia.

De Cecco, M. (2001). Piccole imprese, banche, commercialisti. Note sui protagonisti della seconda industrializzazione italiana. In L. Cafagna, and Crepax N. (Eds.), Atti di intelligenza e sviluppo economico. Saggi per il bicentenario della nascita di Carlo Cattaneo (pp. 425-449). Bologna: Il Mulino. 
De Bruyn, R., \& Della Valle, F. (1997). La banca popolare: i principali tratti storici del modello economico-istituzionale. Credito Popolare, 405-449.

Forestieri, G., \& Tirri, V. (2003). Verso un sistema bancario e finanziario europeo? Quaderni di ricerche Ente Luigi Einaudi.

Ongena, S., \& Smith, D. C. (2000). What determines the number of bank relationships? Cross-country evidence. Journal of Financial Intermediation, 9(1), 26-56.

Penrose, E. T. (1959). The theory of the growth of the firm. Oxford: Basill Blackwell.

Rija, M. (2006). L'investimento istituzionale nel capitale di rischio delle piccole e medie imprese. Metodologie applicative e analisi settoriale. Milano: FrancoAngeli. 